\title{
Perceptions of Students and Teachers about Students' Proficiency in English Language at Higher Secondary Level in Khyber Pakhtunkhwa, Pakistan
}

\author{
Kifayatullah Khan ${ }^{1} \&$ Wasal Khan ${ }^{1}$ \\ ${ }^{1}$ Sarhad University of Science \& Information Technology, Peshawar, Pakistan \\ Correspondence: Kifayatullah Khan, PhD Scholar, Sarhad University of Science \& Information Technology, \\ Peshawar, Pakistan. E-mail: kifayat@aup.edu.pk
}

Received: September 1, 2019 Accepted: November 1, 2019 Online Published: December 10, 2019

doi:10.5539/ijel.v10n1p15 URL: https://doi.org/10.5539/ijel.v10n1p15

\begin{abstract}
This cross-sectional quantitative research was conducted to compare the average perceptions of students and teachers regarding students' English language proficiency at the higher secondary level in Khyber Pakhtunkhwa, Pakistan. The participants were 1975 students and 108 teachers belonging to one each district of the seven divisions in Khyber Pakhtunkhwa, Pakistan. Data were collected through pre-tested questionnaire i.e., one each for students and teachers. To analyze the significance difference between the average perceptions of students and teachers about higher secondary students' English language proficiency; independent samples t-test was applied. The findings of the study revealed significant difference in teachers' and students' perceptions regarding students' partial command over English language; use of English in and beyond classroom; expressing views fluently in English; students' listening, speaking and reading skills; while no significant difference was seen regarding students' full command over English language and their writing skill.
\end{abstract}

Keywords: English language, proficiency in English, students and teachers' perceptions

\section{Introduction}

Being an international and widely spoken global language, English enjoys the status of second and official language in Pakistan since 1947. Since independence, English has been the official and the language of correspondence in all the Government offices, courts and educational institutions (Abbas, Ashiq, \& Haq, 2018). Rehman (2001) argues that English is used extensively in all the powerful and notable institutions such as bureaucracy, judiciary, administration, higher education and military administration. He sees English language as an emblem of power in the hands of these institutions and considers its learning essential for all those who want jobs in these domains of power. Khalid, Akhtar and Hashmi (2017) maintain that English has become a global language due to its extensive use in international business and diplomacy; commerce and trade; and, all social and pure sciences. Above all, it is the language of the 'United Nations and International Court of Justice'.

Proficiency in English language refers to the ability of a student to have command over the spoken and written skills to carry out successful communication while "completing their university studies" (Australian Universities Quality Agency, 2009 cited in Ibrahim et al., 2013). According to Blagojevich, Ruiz and Dunn (2004) English language proficiency refers to the learner's ability to use the English language accurately and fluently to enable him/her to communicate views, ideas and information without any difficulty in all the academic fields i.e., social studies, language and art. Wilson and Komba (2012, p. 2) state, "Language proficiency is the overall ability of an individual in language and a test of proficiency is organized basically into listening, reading, writing and speaking skills".

Proficiency in English language is of prime importance for all students at secondary and higher secondary level because fluency in English ensures one's entry into the higher educational institutions and global workforce (Pawanchik, cited in Ibrahim et al., 2013). Atek, Jusoh, Alias, Wahid and Tahir (2012) state that students' command over English language not only enhances their chances of academic achievements, but also guarantees their better jobs in the market because employers always prefer those graduates who are fluent in English. Thus, students wishing to achieve high academic results and enter the domains of power are required to make extra efforts to obtain proficiency in English language. Yahya et al. (2011) reported that many employers in Malaysia 
declined jobs to many graduates due to their lack of proficiency in English. They further state that these graduates study English as a second language for 11 years, but a majority of them fail to communicate properly in English. Racca and Lasaten (2016) assert that proficiency in English facilitates students' achievement in other academic subjects. They further state that students wishing success in Mathematics, Science and modern Technology are required to have proficiency in English language.

Learning English language has always been a challenge for a majority of Pakistani students. Bhatti, Memon and Pathan (2016) consider students' lack of motivation, shyness, stress and fear of improper evaluation as the major reasons for their ineligibility. Awan, Azher, Anwar, and Naz (2010) opine that one of the major problems faced by Pakistani students in learning English is the lack of their active involvement in the learning process. Majority of the classrooms are teacher-centered and students hardly find any chance to practice English in the classroom. Imran, Asghar and Ghani (2016) attribute this lack of proficiency in English to students' poor knowledge and incorrect use of the parts of speech and articles; Gopang, Ansari, Kulsoom and Laghari (2017) to students' anxiety of learning English language; Haider (2012) to inadequate pedagogical approach; Maldonado Garcia (2018); Panhwar, Baloch and Khan (2017) to traditional methods of teaching English and lack of proper training on the part of English teachers; and, Rasheed (2017) to multilingualism, students' weak linguistic background, lack of exposure to English, students' anxiety of English and lack of teachers' training.

The above mentioned and several other Pakistani studies have focused on students' low proficiency in English at secondary or tertiary level but very few studies have investigated into higher secondary students' perceptions regarding their proficiency in English and the factors affecting it. The current study is an attempt to fill the gap in the research carried out in the area of English language teaching and learning in Pakistan. The main focus of this study was to assess intermediate students' and teachers' perceptions about students' English language proficiency and their awareness about English language teaching and learning situations. The study further attempts to investigate the difference between students' and teachers' perceptions about students' English language proficiency and the factors affecting it. Hence, this study will try to accomplish the following objectives:

1) To explore higher secondary students' and English teachers' perceptions regarding students' proficiency in English and the factors affecting it.

2) To investigate the difference between higher secondary students' and English language teachers' perceptions about students' proficiency in English.

\subsection{Hypotheses of the Study}

The study also tested the following null hypotheses developed for the study:

$\mathrm{H}_{0}$ : There is no difference between students' and teachers' perceptions regarding English language proficiency of students at the higher secondary level.

\section{Literature Review}

According to Ahmad, Ghani, Alam and Sadiq (2012) higher secondary education is of utmost importance because it not only unlocks doors to economic and educational opportunities in the today's world, but also helps the students choose a career of their own choice. Since the world is changing rapidly due to science and technology advancement; therefore, it has become a prerequisite or necessity to get higher secondary education to acquire the required skills to lead a successful life. Similarly, Shoukat and Ghani (2015), claim that higher secondary education widens the horizons of students' intelligence and enables them to lead better quality life. Students with higher education can solve their problems in a friendly way and thus can lead a more socialized and healthy life. So, considerable attention is needed to effective English language teaching-learning to enable students to have a full command over it.

Baker and Westrup (2003) stated that persons with good English communication skills always enjoy an upper hand in every walk of life over those whose communication skill is not up to the mark. The main objective of English language teaching is to inculcate in students' mind all the four language skills so that they may use English efficiently and productively. This will also enable them to communicate their ideas and feelings accurately and appropriately (Davies \& Pearse, cited in Tuan \& Mai, 2015). Proficiency in English ensures students' success in other academic subjects written in and taught through English medium of instructions. Fakeye (2014); Ghenghesh (2015); Aina, Ogundele and Olanipekun (2013) found a significant positive relationship between proficiency in English language and other academic subjects written in English. From their studies it can be concluded that the higher the proficiency level of students in English, the better shall be their understanding of and performance in other academic subjects; particularly, science, mathematics, medical, 
engineering, business and computer science subjects.

Rao (2016) argues that low English language proficiency is the major cause of unemployment and unsuccessful life of engineering and other technical graduates. This is consistent with Orgunsiji's (2009) argument that students' performance in other academic subjects is badly affected by their lack of proficiency in English. Similarly, Theresa and Irvine (2015) posited that weak proficiency among English language learners has always been responsible for their high dropout rates, poor life style and weak approach to well-paid job opportunities. Cabigon (2018) and Digap (2016) claim that proficiency in English language has helped Filipinos in their success in both academic and business fields. All the educational institutions in Philippines have been tasked to produce such skilled workforce that is proficient in English to enable them to put in their efforts for the economic growth of their country at the global level (Quijano, cited in Meniado, 2019).

Mandefro, Mulatu, Abebe and Yona (n.d) conducted a study to examine students' and English language teachers' perceptions towards English language instructions in Schools of Sidama Zone, Ethiopia. The results of the study revealed that $70 \%$ of teachers have no knowledge about teaching strategies and policies that are in practice in the Ethiopian education system. The results further disclosed that $77 \%$ English language teachers showed ignorance about the current English language curriculum and syllabuses. However, a vast majority of the respondent students did not regard learning of English language as difficult and all of them seemed committed to improve their proficiency in English. Moreover, most of the sampled students confirmed that regular interaction in the target language between teachers and students was essential for improving their speaking and practical skills.

Akbari (2016) carried out a research in Isfahan university of Medical Sciences to investigate the MA Paramedical Students' perceptions about their problems, needs and concerns over learning English. On the basis of her findings, she came to the conclusion that majority of the MA students were not proficient enough to express their views fluently in English or write error free English articles. Moreover, the present curriculum of English for Academic Purpose was inconsistent with the perceived needs and interests of the students. Furthermore, it was found that a vast majority of the students were not happy with their reading and writing skills and grammatical knowledge; however, their satisfaction with their technical vocabulary was much greater than their general vocabulary.

Souriyavongsa, Rany, Abidin and Mei (2013) conducted a study in Laos to find out the student-teachers' perceptions about students' low proficiency in English language. The respondents were 15 male and 15 female students selected through purposive sampling method. A majority of the students regarded lack of proper training on the part of English language teachers in teaching English, lack of proper English background knowledge, lack of confidence due to fear of making mistakes, lack of constant practice to speak English and lack of proper curriculum as major causes of students' weakness in English language.

Shahzad, Ali, Hukamdad, Qadeer, and Habibullah (2011) conducted a research to find out the reasons behind students' low achievements in the subject of English and came to the conclusion that overcrowded classroom; lack of encouraging learning environment in the classroom; incompetent and unskilled English language teachers were responsible for students' poor performance in the subject of English. Hamouda (2012) carried out research study on 6 Saudi EFL learners. Data were collected through questionnaire and interviews. The results showed that the students' main listening comprehension problems were pronunciation, speed of the speaker, inadequate vocabulary knowledge, different accent of speakers, lack of proper attention, anxiety, and bad quality of recording.

Qutob (2018) conducted a research study to investigate students' perceptions on EFL speaking skill development. The results of the study revealed that all the respondents considered speaking as the most important skill and they all showed a strong desire to master it. The participants showed a great satisfaction with their classroom environment, available materials, teachers' efficiency and activities being practiced in the classroom. However, the respondents seemed a bit dissatisfied with the time allotted for speaking practice. Tuan and Mai (2015) conducted a study to investigate teachers' and students' perceptions towards the problems faced by Vietnamese students in learning speaking skills. The respondents were two hundred and three 11 grade students and 10 English teachers. The findings of the study revealed a close association between teachers' and students' perceptions. The major factors that affected students' speaking skills were:

(i) Little or no English-speaking practice in the class

(ii) Use of Vietnamese instead of English in the classroom

(iii) Lack of motivation towards English language

(iv) Fear of being laughed at by their classmates. 
Iqbal, Hassan and Alil (2015) conducted qualitative and quantitative research to find the reasons behind poor reading comprehension of secondary students. Their study revealed that the main factor behind students' poor English reading comprehension was their lack of vocabulary knowledge. They further found that students were unable to guess the meaning from the text but rather tried to find the actual meaning of the word. Alshehri (2014) and Landaverde (2013) concluded from their results that loud reading and good background knowledge are necessary for improving students' reading comprehension skill and understanding authentic texts. Fareed, Ashraf and Bilal (2016) conducted a research study on Pakistani undergraduate ESL learners' writing problems. Data were collected from 30 undergraduate ESL students and 10 teachers. The findings of the study revealed that lack of command over grammar, poor vocabulary, syntax, writing anxiety, too much dependence on L1 and lack of ideas were the problems faced by the undergraduate ESL learners in their writing. Butt and Rasul (2012) carried out a study to analyze Pakistani teachers' perspectives regarding error committed by degree level students while writing in English. Both qualitative and quantitative approaches were applied to analyze the data. The results of the study revealed that too much reliance on L1, overcrowded classroom, lack of sound background of English language and students' lack of motivation were the major causes for students' error in writing.

Waseem, Naveed and Aziz (2015) argue that a huge number of Pakistani students have no proficiency in English language which proves to be a great hurdle in their academic achievement. They make use of all the possible means to get proficiency in English language but always fail to do so. They join private English language centers to improve their language skills yet they fail to show good results even in the subjects taught through English. No doubt, they do comprehend and have a clear understanding of a topic but still lack the ability to express their feelings and opinions about it in correct English. Aziz and Quraishi (2017) believe that many secondary school students in Pakistan show good results in other academic subjects, but their results in the subject of English are always discouraging. Keeping this important fact in view, this current study was planned to investigate higher secondary school students' and English language teachers' perceptions about students' proficiency in English and the factors affecting it.

\section{Methodology of the Study}

\subsection{Population of the Study}

All the $11^{\text {th }}$ and $12^{\text {th }}$ grade students of the Government Higher Secondary Schools and Colleges (only boys) enrolled in the session 2016-2017 in the Khyber Pakhtunkhwa, Pakistan constituted the population of the study. Since it was not possible to collect the data from all the 25 districts, therefore, seven districts were randomly selected. The total number of students in these seven districts was 74,041. The population also included Subject Specialist (SS) and lecturers involved in teaching English to the aforementioned classes throughout the province. The total number of these SS and lecturers was 370 (Source E \& SE).

\subsection{Sample}

As mentioned above, all the $11^{\text {th }}$ and $12^{\text {th }}$ grade students of Government higher secondary schools and Colleges in Khyber Pakhtunkhwa, Pakistan are the target population. A multi-stage sampling procedure was followed. In stage 1, out of all seven administrative divisions, one district from each division was purposively selected. In stage 2 , from each selected district, a minimum of 10 or above schools were randomly selected. The total number of the sampled schools and colleges was 89 ( 29 urban and 60 rural). Then in stage 3, at least 24 students from each school were randomly selected. Thus, the total number of sampled students was 2136 . In addition to students, 125 subject specialists and lecturers were also randomly selected from these schools with a minimum of one Subject Specialist from each Government higher secondary school and two lecturers from each college. While selecting schools and colleges, it was kept in mind that the data represented the whole population and all factors.

\subsection{Construction of the Questionnaires}

Two close-ended questionnaires (one each for students and English teachers) were developed to collect the data from the sampled students and teachers of the sampled institutions. The main purpose behind using close-ended questions was to make them easier and less time consuming for the respondents to fill, and to obtain information according to the objectives of the given study.

\subsection{Data Collection}

The investigator personally visited all the sampled schools and colleges and administered the questionnaires to the sampled teachers and students after obtaining permission from the concerned principals. With the permission of the principals, the researcher randomly selected 24 students, twelve each, from $11^{\text {th }}$ and $12^{\text {th }}$ classes and briefed them thoroughly about filling the questionnaire. The researcher supervised the whole process of the 
filling up the questionnaires. The total number of the students' filled questionnaires was 1975 and that of teachers was 108 .

\subsection{Validity and Reliability of the Questionnaires}

Content validity and face validity were ensured by reviewing the instruments through a panel of experienced English teachers and researchers having $\mathrm{PhD}$ degrees in the field. They thoroughly reviewed the questionnaires and declared the instruments to be clear, useful and valid for the purpose in hand (Alnaqeeb, 2012; Kalsoom, 2013; Butt, 2011).

Cronbach alpha coefficient (the most widely used measure) was used for checking the reliability of the collected data from students and teachers about different attributes of promoting students' regarding English language proficiency at the higher secondary level. The data were considered reliable having Cronbach Alpha coefficient greater than or equal to 0.70 .

\subsection{Data Analysis}

To investigate significant differences, if any, between the average perception of students and teachers regarding students' English language proficiency, independent samples t-test was applied. For convenience, t-test is given in equation:

$$
t=\frac{\bar{X}_{1}-\bar{X}_{2}}{s_{p} \sqrt{1 / n_{1}+1 / n_{2}}}
$$

Table 1. Comparison of average perception of students and teachers regarding students' proficiency in English language.

\begin{tabular}{|c|c|c|c|c|c|}
\hline Attribute & Group & Mean & SD & t-ratio & P-value \\
\hline \multirow[t]{2}{*}{ Q1. Students have full command over English language } & Students & 1.21 & 0.547 & 0.883 & 0.377 \\
\hline & Teachers & 1.16 & 0.532 & & \\
\hline \multirow[t]{2}{*}{ Q2. Students have partial command over English language. } & Students & 2.68 & 0.711 & 5.207 & 0.000 \\
\hline & Teachers & 2.19 & 0.952 & & \\
\hline \multirow[t]{2}{*}{ Q3. Students have to speak English in English class only. } & Students & 1.81 & 0.962 & -5.906 & 0.000 \\
\hline & Teachers & 2.34 & 0.909 & & \\
\hline \multirow[t]{2}{*}{ Q4. Students face problems while expressing views in English fluently. } & Students & 2.49 & 0.816 & -2.740 & 0.007 \\
\hline & Teachers & 2.69 & 0.719 & & \\
\hline \multirow[t]{2}{*}{ Q5. Students use English when find an opportunity to do so. } & Students & 2.18 & 0.975 & 2.402 & 0.016 \\
\hline & Teachers & 1.94 & 0.965 & & \\
\hline \multirow[t]{2}{*}{ Q6. Communication in English has always been a problem for students. } & Students & 2.63 & 0.742 & -3.500 & 0.001 \\
\hline & Teachers & 2.82 & 0.561 & & \\
\hline \multirow[t]{2}{*}{ Q7. Students cannot improve English despite best efforts. } & Students & 2.06 & 0.979 & 7.819 & 0.000 \\
\hline & Teachers & 1.46 & 0.766 & & \\
\hline \multirow[t]{2}{*}{ Q8. Students easily understand whatever listens to in English. } & Students & 1.40 & 0.743 & -2.421 & 0.017 \\
\hline & Teachers & 1.60 & 0.853 & & \\
\hline \multirow[t]{2}{*}{ Q9. Students easily comprehend whatever read in English. } & Students & 1.57 & 0.848 & 2.408 & 0.018 \\
\hline & Teachers & 1.40 & 0.735 & & \\
\hline \multirow[t]{2}{*}{ Q10. Students can write correct English. } & Students & 1.51 & 0.818 & 0.346 & 0.730 \\
\hline & Teachers & 1.48 & 0.791 & & \\
\hline
\end{tabular}

In the Table students' and teachers' mean scores (1.21) and (1.16) clearly show students' lack of full command over English language. The p value (0.377) also exhibits great similarity in the students' and teachers' perceptions about students' lack of command over English language. However, significant difference was seen while comparing the mean scores of students and teachers regarding students' partial command over English language. A majority of the students (2.68) claim that they have partial command over English language but they show uncertainty (1.81 and 2.18) while responding to Q. No. 3 and 5. However, teachers' responses show uncertainty to Q. No. 2. In response to Q. No. 3, a majority of the teachers (2.34) claim that students have to speak in English in the English classroom but they negate their own claim while responding to Q. No. 5, where they show uncertainty (1.94) about students' use of English when they have an opportunity to do so. Close similarity was seen in students' and teachers' responses while replying to Q. No. 4 and 6. A dominant majority of the students (2.49 and 2.63) maintained that they faced problems while expressing their views in English. 
They further stated that communication in English had always been a problem for them. The teachers' responses strongly supported student' claims as is evident from their mean scores (2.69 and 2.82).

Statement No. 7 illustrates the mean score of students as $2.06, \mathrm{SD}=0.979$ and the mean score of teachers as 1.46, $\mathrm{SD}=0.766$ but the $\mathrm{t}-$ value is 7.819 with $\mathrm{p}<0.05$ which shows significant difference between students and teachers' perceptions about students' efforts for improving their English language. Similarly clos similarity was observed in students' and teachers' responses to Q. No. 8, 9 and 10. Students mean score (1.40) clearly showed that they did not understand whatever they listened to in English but their mean scores (1.57 and 1.51) demonstrated their little uncertainty to statement No. 9 and 10. However, the mean scores of teachers' responses i.e. $(1.40,1.40$ and 1.48) clearly indicated that students neither understood whatever they listened to in English, nor comprehended whatever they read nor could write correct English.

As evident from table, the p-value in statement No. 2, 3, 4, 5, 6, 7, 8 and 9 is less than 0.05 which shows significant difference between teachers and students' perceptions, hence, the null hypothesis is rejected whereas in case of statements No. 1 and 10 the null hypothesis is accepted.

Table 2. Comparison of average perceptions of students and teachers regarding the factors affecting students' proficiency in English language.

\begin{tabular}{|c|c|c|c|c|c|}
\hline Attribute & Group & Mean & SD & t-ratio & P-value \\
\hline \multirow{2}{*}{$\begin{array}{l}\text { Q11. Students always use language other than English in discussion and asking } \\
\text { questions. }\end{array}$} & Students & 2.70 & 0.691 & 1.912 & 0.058 \\
\hline & Teachers & 2.56 & 0.789 & & \\
\hline \multirow[t]{2}{*}{ Q12. Students feel shy and lack confidence while speaking English. } & Students & 2.18 & 0.968 & 4.847 & 0.000 \\
\hline & Teachers & 2.87 & 0.946 & & \\
\hline Q13. English teacher arranges activities that arouse students' interest in learning & Students & 1.33 & 0.699 & -30.644 & 0.000 \\
\hline English. & Teachers & 2.83 & 0.483 & & \\
\hline \multirow[t]{2}{*}{ Q14. Teachers encourage students to learn new English vocabulary. } & Students & 1.97 & 0.959 & -26.876 & 0.000 \\
\hline & Teachers & 2.94 & 0.301 & & \\
\hline \multirow[t]{2}{*}{ Q15. Teacher uses different methods to improve students' English language skills. } & Students & 1.69 & 0.862 & -19.786 & 0.000 \\
\hline & Teachers & 2.78 & 0.535 & & \\
\hline \multirow[t]{2}{*}{ Q16. English teacher usually uses language other than English while teaching. } & Students & 1.69 & 0.762 & 6.585 & 0.000 \\
\hline & Teachers & 2.78 & 0.962 & & \\
\hline \multirow[t]{2}{*}{ Q17. School and classroom environment is conducive for learning English. } & Students & 1.84 & 0.931 & -0.313 & 0.754 \\
\hline & Teachers & 1.87 & 0.948 & & \\
\hline \multirow[t]{2}{*}{ Q18. There are more than 40 students in the class. } & Students & 2.80 & 0.591 & 1.659 & 0.100 \\
\hline & Teachers & 2.69 & 0.732 & & \\
\hline \multirow[t]{2}{*}{ Q19. Students belong to educated families. } & Students & 1.32 & 0.708 & -1.219 & 0.225 \\
\hline & Teachers & 1.41 & 0.762 & & \\
\hline
\end{tabular}

A majority of the responding students $78.2 \%$ indicated that teachers use languages other than English while teaching English but teachers rejected students' view in this regard.

Significant difference was observed in the mean scores of students and teachers while comparing teachers' and students' claims regarding teachers' motivating students to learn new English vocabulary to improve their English. A huge majority of teachers $86.1 \%$ (2.83) claim that they encourage students to learn new vocabulary and arrange various activities to arouse students' interest in learning English; however, a majority of the students $71.8 \%$ (1.33) reject teachers' views. The lack of such activities in the classroom seems to be the main reason behind students' anxiety and lack of confidence while speaking English.

Further, a large majority of teachers $83.3 \%$ claim that they use different methods to improve students' proficiency in English but a small majority of students 57.6\% disagree with teachers' views. Both students' and teachers' mean scores also show significant difference in their views as the $p$ value is less than 0.05 .

Interestingly, no significant difference was seen in uncertainty of students and teachers while comparing their perceptions about the suitability of school and classroom environment for learning English. Their mean scores (1.84 and 1.87) and $p$ value 0.754 higher than 0.05 ensure the same. Both the students and teachers agreed that the number of students in the classrooms was more than 40 . The $p$ value 0.10 also shows no significant difference in students' and teachers' views about the number of students in the classroom.

As evident from table, the p-value in statement No. 12, 13, 14, 15 and 16 is less than 0.05 which shows significant difference between teachers and students' perceptions, hence, the null hypothesis is rejected whereas 
in case of statements No. 11, 17, 18 and 19 the null hypothesis is accepted.

\section{Discussion}

Both the teachers and students agree that students at the higher secondary level have no command over English language and they cannot write correct English. They do pass the examinations but find it difficult to communicate their ideas, feelings and opinions in the target language. These findings are in line with the findings of Waseem, Naveed and Aziz (2015) that majority of Pakistani students lack proficiency in English language and despite their clear understanding of a topic, they cannot express themselves in writing. Similarly, Kellog and Raulerson (2007, p. 237) regard writing as a 'major cognitive challenge, because it is at once a test of memory, language, and thinking ability'.

As evident from the table, the majority of the students lacked fluency in English and could not understand what they listened to in English. Moreover, they disagreed that they comprehended or interpreted the meaning of the materials written in English. On the basis of this research finding, many factors were responsible for this low proficiency of the students at the higher secondary level. There was no or little use of English language for communication both in classrooms and beyond the classroom which is a basic requirement for obtaining proficiency in the target language. There was always a dominant use of the mother tongue even in the English class as evident from the students' opinion. These results are in line with the findings of Al-Mahrooqi (2012) and Rasheed (2017) whose findings indicated that a majority of the students avoid using English in the classrooms or outside the classroom for fear of being laughed at by their peers.

Teachers themselves used language other than English and mostly relied on grammar-translation method. These results support the findings of Shamim (2009, p. 5) who asserted that "In public sectors schools, English is taught using the grammar-translation method through Urdu and/or in local languages in the crowded and under resourced classrooms".

The lack of constant practice of the four language skills is also responsible for the lack of students' proficiency in English language. Majority of the students (57.5\%) said that they used English as a medium of communication neither in schools nor in classrooms. These results are similar in nature as reported by Wingate's (2006) when he said that students have problems with academic writing because teachers do not make them practice essay writing. Similar were the findings of Teevno (2012) that a few of teachers and students use English language in classrooms.

\section{Conclusions}

Keeping the findings of the study in view, the following conclusions were drawn:

The findings of the study highlight the fact that majority of the students lack proficiency in English language but have partial command over it. Except few, most of the students lack proficiency in almost all the four language skills i.e., listening, speaking, reading and writing. Bilal, Rehman, Rashid, Adnan and Abbas (2013) and Akbari (2015) confirm the findings of the study by stating that most of the students at secondary level can't communicate reasonably in English even after reading it for 7 to 10 years. The result is that most of the students at the higher secondary level face problems while communicating in English because they neither understand what they listen to in English nor can they comprehend what they read nor can they write correct English. The main reason behind this deficiency is the lack of practice because the results show that students practice English neither inside nor outside the school nor with teachers.

These findings are in line with the findings of Nawab (2012) who concluded that the main reason behind students' lack of proficiency is the lack of constant practice and exposure to various language activities in the classroom. Dr. Kannan (2009) upholds the same view that learning English requires a lot of patience and adequate practice on the part of the learners. He further states that most of the students study English for a long time but fail to produce a single error free sentence.

\section{Recommendations}

In the light of the conclusions drawn out of the findings of the study, the following suggestions are given to promote and facilitate students' English language proficiency:

- Keeping the students' low proficiency in English at the higher secondary level in view, it is imperative that they need to be exposed to all the four language skills and raise their awareness by highlighting the international status of English language.

- Teachers should encourage students to communicate in English not only inside and outside the classroom, but also at home to address their oral communication skill. It is possible only when the teachers themselves 
avoid the use of languages other than English.

- Teachers should create such an environment inside and outside the classroom where students feel no hesitation to communicate in English language.

- Students should be encouraged to listen to BBC English, CNN, English documentary and other TV programmes. They may discuss with friends and class fellows what they listen to.

- Teachers should encourage students to develop extensive reading and writing habits for improving their reading and writing skills because good reading habits can enhance effective learning of English.

- Teachers should encourage students to use only English language in the classroom while discussing any topic with their class fellows and other friends to improve their speaking skill.

\section{Acknowledgement}

This research paper titled "Perceptions of Students and Teachers about Students' Proficiency in English Language at Higher Secondary Level in Khyber Pakhtunkhwa- Pakistan" has been extracted from the PhD Thesis titled "An Analysis of the Factors Promoting English Language Proficiency of Students at Higher Secondary Level in Khyber Pakhtunkhwa, Pakistan" which was conducted by Kifayatullah Khan under the supervision of Associate Prof. Dr. Wasal Khan, Faculty of Education, Sarhad University of Science and Information Technology Peshawar,Pakistan and is being published in partial fulfillment of the requirements for the degree of $\mathrm{PhD}$ in Education at Sarhad University of Science and Information Technology Peshawar, Pakistan.

\section{References}

Abbas, N., Ashiq, U., \& Abrarulhaq, M. (2018). Gap between acquired and required English learning objectives for the primary school students: Empirical evidence from Sargodha (Pakistan). Cogent Social Sciences, 4, 1457421. https://doi.org/10.1080/23311886.2018.1457421

Ahmad, K., Ghani, M., Alam, M., \& Sadiq, M. (2012). Washback effects on English language teachers. International Researcher, 1(3), 181-190.

Aina, J. K., Ogundele, A. G., \& Olanipekun, S. S. (2013). Students' proficiency in English language relationship with academic performance in science and technical education. American Journal of Educational Research, 1(9), 355-358.

Akbari, Z. (2016). The study of EFL students' perceptions of their problems, needs and concerns over learning English: The case of MA Paramedical Students. Procedia - Social and Behavioral Sciences, 232, 24-34. https://doi.org/10.1016/j.sbspro.2016.10.006

Al-Mahrooqi, R. (2012). A Student perspective on low English proficiency in Oman. International Education Studies, 5(6). https://doi.org/10.5539/ies.v5n6p263

Alnaqeeb, A. M. A. (2012). A Study of Yemni English teachers' classroom practices and approaches with special reference to secondary schools in Laboos. PhD Thesis, The University of Pune, India.

Alshehri, M. (2014). Improving reading comprehension for Saudi students by using the reading aloud strategy. Fredonia, Master Thesis, State University of New York, Fredonia.

Atek, E. S. E., Josoh, J., Alias, A. N., Wahid, A. W., \& Tahir, I. M. (2012). Students' attitudes towards the English proficiency enhancement program. International Journal of Education, 4(3), 1-11. https://doi.org/10.5296/ije.v4i3.1475

Awan, R., Azher, M., Anwar, M. N., \& Naz, A. (2010). An investigation of foreign language classroom anxiety and its relationship with students' achievement. Journal of College Teaching \& Learning, 7(11), 33-40. https://doi.org/10.19030/tlc.v7i11.249

Aziz, F., \& Quraishi, U. (2017). An insight into secondary school students' beliefs regarding learning English language. Cogent Education, 4, 1-9. https://doi.org/10.1080/2331186X.2017.1278835

Baker, J., \& Westrup, H. (2003). Essential speaking skills: A Handbook for English Language Teachers. London: Continuum.

Bhatti, N., Memon, S., \& Pathan, H. (2016). Investigating the perceptions of Pakistani English language learners on language learning anxiety in EFL classroom. Advances in Language and Literary Studies, 7(5), 23-34. https://doi.org/10.7575/aiac.alls.v.7n.5p.23

Blagojevich, R. R., Ruiz, J., \& Dunn, R. J. (2004). Illinois English Language Proficiency Standards for English 
Language Learners (K-12). Chicago: Illinois State Board of Education.

Butt, M. I., \& Rasul, S. (2012). Errors in the writings of English at degree level: Pakistani teachers' perspectives. Language in India, 12, 195-217.

Butt, N. (2011). Impact of Non-Verbal Communication on Students' Learning Outcomes. PhD Thesis, Faculty of Arts, Social Sciences \& Education Sarhad University of Science and Information Technology, PeshawarPakistan.

Cabigon, M. (2018). State of English in the Philippines: Should we be concerned? Retrieved from https://www.britishcouncil.ph/teach/state-english-philippines-should-we-be-concerned-2

Digap, A. L. (2016). Self-efficacy, English proficiency and effectiveness of teachers of English in the secondary schools. SMCC Higher Education Research Journal, 2(April), 72-88. https://doi.org/10.18868/sher2j.02.00416.07

Fakeye, D. (2014). English language proficiency as a predictor of academic achievement among EFL Students in Nigeria. Journal of Education and Practice, 5(9), 38-41.

Fareed, M., Ashraf, A., \& Bilal, M. (2016). ESL learners' writing skills: problems, factors and suggestions. Journal of Education and Social Sciences, 4(2), 81-92. https://doi.org/10.20547/jess0421604201

Ghenghesh, P. (2015). The relationship between English language proficiency and academic performance of university students - Should academic institutions really be concerned? International Journal of Applied Linguistics \& English Literature, 4(2), 91-97. https://doi.org/10.7575/aiac.ijalel.v.4n.2p.91

Gopang, I. B., Ansari, S., Kulsoom, U., \& Laghari, A. (2017). An empirical investigation of foreign language anxiety in Pakistani university. International Journal of English Linguistics, 7(2), 21. https://doi.org/10.5539/ijel.v7n2p21

Haider, G. (2012). Teaching of writing in Pakistan: A review of major pedagogical trends and Issues in teaching of writing. Journal of Educational and Social Research, 2(3), 215-225.

Hamouda, A. (2012). Listening comprehension problems: Voices from the classroom. Language in India, 12(8), $1-49$.

Ibrahim, Z. S., Hassali, M. A., Saleem, F., Haq, N. U., Khan, T. M., \& Aliadhey, H. (2013). Perceptions and barriers towards English language proficiency among pharmacy undergraduates at Universiti Sains Malaysia. Pharmacy Education, 13(1), 151-156.

Imran, M., Asgher, T., \& Ghani, M. (2016). A study on science students' understanding of Three Lemmas: State Verb, Action Verb and Noun in the State Run Colleges in Pakistan. International Journal of English Linguistics, 6(5), 121. https://doi.org/10.5539/ijel.v6n5p121

Iqbal, M. N., Hassan, M. U., \& Ali, M. Q. (2015). Assessing quality of English teachers at secondary level in Punjab, Pakistan. Journal of Elementary Education, 25(1), 75-90.

Kalsoom, T. (2013). Teaching Grammar: Relationship between English Language Teachers' Beliefs and Practices. PhD Thesis: Institute of Education and Research, University of the Punjab, Lahore-Pakistan.

Kannan, R. (2009). Difficulties in learning English as a Second Language. ESP World, 8(26). Retrieved from http://www.esp-world.info

Kellogg, R. T., \& Raulerson III, B. A. (2007). Improving the writing skills of college students. Psychonomic Bulletin \& Review, 14(2), 237-242. https://doi.org/10.3758/BF03194058

Khalid, M., Akhter, M., \& Hashmi, A. (2017). Teaching styles of secondary school English teachers and learning styles of their students and relationship of teaching learning style match with students' achievement. Bulletin of Education and Research, 39(3), 203-220.

Landaverde, C. A. (2013). Factors that affect in the development of Reading Comprehension process of 4th year English major students when reading authentic texts. Bachelor Thesis, University of El Salvador.

Maldonado Garcia, M. I. (2018). Improving university students' writing skills in Pakistan. The European Educational Researcher, 1(1), 1-16. https://doi.org/10.31757/euer.111

Mandefro, E., Mulatu, M., Abebe, T., \& Yona, Y. (n.d.). Perception of students and English Language teachers towards English Language Instruction: The case of schools in Sidama Zone, Ethiopia. International Journal of Humanities and Social Sciences, 8(4), 1-9. 
Meniado, J. C. (2019). Evaluating the English proficiency of faculty members of a higher education institution: Using results to develop responsive professional development program. International Journal of English Linguistics, 9(2), 52-64. https://doi.org/10.5539/ijel.v9n2p52

Nawab, A. (2012). Is it the way to teach language the way we teach language? English language teaching in rural Pakistan. Academic Research International, 2(2), 696-705.

Orgunsiji, Y. (2009). English language proficiency as a predictor of academic achievement among EFL students in Nigeria. European Journal of Scientific Research, 37(3), 490-495.

Panhwar, A. H., Baloch, S., \& Khan, S. (2017). Making communicative language teaching work in Pakistan. International Journal of English Linguistics, 7(3), 226-234. https://doi.org/10.5539/ijel.v7n3p226

Qutob, M. M. (2018). The relationship between EFL learners' satisfaction within the classroom environment and their speaking skills. English Language Teaching, 2(7), 116-124. https://doi.org/10.5539/elt.v11n7p116

Racca, R. M. A. B., \& Lasaten, R. C. S. (2016). English language proficiency and academic performance of Philippine science high school students. International Journal of Languages, Literature and Linguistics, 2(2), 44-49. https://doi.org/10.18178/IJLLL.2016.2.2.65

Rao, V. C. S. (2016). A brief study of English language proficiency: Employability. English for Specific Purposes World, 49(17), 1-9.

Rasheed, S., Zeeshan, M., \& Zaidi, N. A. (2017). Challenges of teaching English language in a multilingual setting: An investigation at Government girls secondary schools of Quetta, Baluchistan, Pakistan. International Journal of English Linguistics, 7(4), 149-157. https://doi.org/10.5539/ijel.v7n4p149

Rehman, T. (2001). All about Life Styles. Dawn, 14 ${ }^{\text {th }}$ June 2001.

Shahzad, S., Ali, R., Hukamdad, Q. M., \& Habibull, Z. (2011). Identification of the Causes of Students' Low Achievement in the Subject of English. Asian Social Science, 7(2), 168-171. https://doi.org/10.5539/ass.v7n2p168

Shamim, F. (2009). English as the language for development in Pakistan: Issues, challenges and possible solutions. In H. Coleman (Ed.), Dreams and realities: Developing countries and the English language (pp. 291-309). Retrieved $\quad$ September $10, \quad 2017$ from http://www.teachingenglish.org.uk/sites/teacheng/files/Z413\%20English\%20Development\%20Book.pdf

Shoukat, B., \& Ghani, M. (2015). English language teachers' opinion on intermediate English textbooks taught in Punjab Pakistan. Dialogue, 10(3), 313.

Souriyavongsa, T., Rany, S., Abidin, M. J. Z., \& Mei, L. L. (2013). Factors causes students low English language learning: A case study in the National University of Laos. International Journal of English Language Education, 1(1), 179-192. https://doi.org/10.5296/ijele.v1i1.3100

Teevno, R. A. (2011). Challenges in teaching and learning of English at secondary level Class X. International Journal of Human Resource Studies, 1(2), 27-35. https://doi.org/10.5296/ijhrs.v1i2.1029

Theresa, A., \& Irvine, D. (2015). Predictors of Latino English learners' reading comprehension proficiency. Journal of Educational Research and Practice, 5(1), 35-57.

Tuan, N. H., \& Mai, T. N. (2015). Factors Affecting Students' Speaking Performance at Le Thanh Hien High School. Asian Journal of Education Research, 3(2), 8-23

Waseem, F., Naveed, A., \& Aziz, S. (2015). Does schooling make a difference in English Language Proficiency? A comparison of Pakistani undergraduate students coming from English and Urdu medium schools. European Academic Research, 3(8), 8628-8652.

Wilson, J., \& Komba, S. C. (2012). The link between English language proficiency and academic performance: A pedagogical perspective in Tanzanian secondary schools. World Journal of English Language, 2(4), 1-10. https://doi.org/10.5430/wjel.v2n4p1

Wingate, U. (2006). Doing away with the study skills. Teaching in Higher Education, 11(4), 457-469. https://doi.org/10.1080/13562510600874268

Yahaya, A., Yahaya, N., Lean, O. C., Bon, O. T., \& Ismail. S. (2011). Factors contributing to proficiency in English as a second language among Chinese students in Johor Bahru. Elixir Psychology, 41, 5837-5848. 


\section{Copyrights}

Copyright for this article is retained by the author, with first publication rights granted to the journal.

This is an open-access article distributed under the terms and conditions of the Creative Commons Attribution license (http://creativecommons.org/licenses/by/4.0/). 